DOI 10.37882/2223-2982.2020.08.13

\title{
«ЧТОБЫ В ДАЛЬНЕЙШЕМ СОКРАЩЕНИЕ МОНАСТЫРЕЙ И СКИТОВ ПРОХОДИЛО ТОЛЬКО ПО ЦЕРКОВНОЙ ЛИНИИः: ВЛАСТЬ И ЦЕРКОВЬ В ЭПОХУ НОВОЙ ВОЙНЫ С РЕЛИГИЕЙ В УКРАИНСКОЙ ССР В 1958-1959 ГГ.
}

\begin{abstract}
«TO FURTHER THE REDUCTION OF MONASTERIES AND HERMITAGES WERE ONLY ON THE CHURCH LINE»: GOVERNMENT AND CHURCH IN THE ERA OF A NEW WAR OF RELIGION IN THE UKRAINIAN SSR IN 1958-1959
\end{abstract}

\section{S. Goyuk}

Summary: This article analyzes the content and nature of changes in the Church policy of the government of N.S. Khrushchev, caused by the strengthening of supporters of the "hard» course of state-religious relations among the highest party circles. On the basis of materials, the Board studied conducting in 1958-1959 the first phase of the destruction of the monasteries on the territory of the Ukrainian SSR - the region with the most religious population and the large number of communities, identified problems of interaction of the Council with the party and state bodies, the working methods, the public reaction to anti-Catholic actions of the government.

Keywords: Russian Russian Orthodox Church, Russian Orthodox Church, Orthodox monasteries, political war with religion, state-Church relations, Plenipotentiaries.

\author{
Гоюк Серафим Михайлович \\ иерей, аспирант, Московская духовная академия, \\ 2. Сергиев Посад \\ samgoyuk@yandex.ru
}

Аннотация: В настоящей статье анализируются содержание и характер изменений в церковной политике правительства Н.С. Хрущева, вызванные усилением сторонников «жесткого» курса государственно-религиозных отношений из числа высших партийных кругов. На основе материалов Совета изучено проведение в 1958-1959 гг. первого этапа уничтожения монастырей на территории Украинской ССР - регионе с самым религиозным населением и большим количеством обителей, выявлены проблемы взаимодействия Совета с партийными и государственными органами, методы работы, реакция населения на антицерковные действия власти.

Ключевые слова: советское государство, Совет по делам Русской Православной Церкви, Русская Православная Церковь, православные монастыри, политическая война с религией, государственно-церковные отношения, уполномоченные.
$\mathrm{O}$ дна из самых масштабных антицерковных кампаний в СССР, названная в отечественной историографии «хрущевскими» гонениями, проходила в 1958-1964 гг. и стала последней крупной попыткой советского государства положить конец существованию православия в стране. Старт наступлению атеистического государства на Московскую Патриархию был дан 4 октября 1958 г. с выходом постановления ЦК КПСС «О записке отдела пропаганды и агитации ЦК КПСС по союзным республикам “О недостатках научно-атеистической пропаганды"». Этот документ ознаменовал окончательный поворот от сталинского «нового курса» государственноконфессиональных отношений в сторону жесткого давления на Церковь с дальнейшим ее полным вытеснением из жизни советского народа.

Постановление ЦК, ставшее идеологической основой кампании, вскоре было уточнено новым документом - 16 октября 1958 г. Совет Министров СССР принял постанов- ление «О православных монастырях в СССР». Кроме введения значительных ограничений (административных, финансово-экономических, юридических) деятельности православных монастырей республиканские власти получили приказ в 6-месячный срок подготовить плановые списки монастырей для ликвидации в 1959 г. По самым скромным подсчетам к началу антирелигиозного наступления - в 1958 г. паства Русской Православной Церкви составляла около 60 млн прихожан, что вызывало вполне обоснованную тревогу атеистически настроенной власти [1].

Как справедливо утверждает Т.А. Чумаченко, кампания 1958-1964 гг. была инициирована и контролировалась исключительно высшими партийными кругами, что обусловило ее жестокость в отношении Московской Патриархии [2]. В течение 1958-1959 гг. Совет по делам Русской Православной Церкви во главе с Г.Г. Карповым неоднократно предпринимал попытки «остудить» пыл 
республиканских и региональных партийно-государственных органов при проведении ликвидации монастырей и храмов.

На территории Украины первым шагом в наступлении на Московскую Патриархию стало постановление Совета Министров УССР от 1 ноября 1958 г. № 1549. В течение месяца уполномоченный Совета по УССР Г.П. Пинчук совместно с республиканскими партийными кругами разработал план сокращения монастырей и ограничения паломничеств к святым местам, в котором предлагал разрешить местным уполномоченным помогать органам власти при ликвидации гостиниц для паломников в Киево-Печерской и Почаевской лаврах; информировать местных властей о персональном составе прибывающих паломников и адресах их проживания для дальнейшего преследования; запретить монастырям принимать большие группы паломников, снабжать их деньгами и продовольствием; предупредить «церковные круги» о нецелесообразности проведения крестных ходов с мощами и богослужений возле водных источников. Весь декабрь 1958 г. Г.П. Пинчук неоднократно встречался в Киеве с областными уполномоченными, консультировал их, предметно изучал возможности закрытия каждого монастыря в отдельности [3].

Отдельное внимание он обращал на борьбу с популярностью широко известного преподобного Кукши (Величко), собиравшего вокруг себя многочисленных верующих со всех концов страны. Уполномоченный предлагал «рекомендовать» Московской Патриархии перевести святого из Богословского монастыря Черниговской области куда-либо за пределы Украины, чтобы ограничить его почитание верующими [4].

Значительной проблемой для власти стала деятельность преподобного Иова (Кундри), настоятеля Троицкого скита Никольского монастыря с. Иза Закарпатской области. По данным местного уполномоченного А.Г. Шерстюка, несмотря на письменное распоряжение епископа об ограничении приема новых лиц в скит, он «проявлял большую активность при приеме молодежи послушниками в скит и в духовную семинарию». Называя преподобного «большим фанатиком», уполномоченный подчеркивал его отказ следовать распоряжениям архиепископа Варлаама о сокращении насельников, а также сообщал о возбуждении уголовного дела за незаконную покупку колокола на базе Тячевского райпотребсоюза [5].

Конкретные предложения о закрытии обителей с анализом отношения местного населения к кампании также начали поступать в Совет вместе с информационными докладами уполномоченных о работе за 1958 г. Среди характерных аргументов, используемых уполномоченными для подтверждения необходимости ликвидации монастырей, указывались слабое экономическое положение, незначительная популярность у паломников из других регионов, расположение вблизи социальных учреждений (школ, детских садов, приютов, больниц) [6].

Уполномоченные областей с высоким уровнем религиозности населения прекрасно осознавали возможность протестов со стороны верующих при закрытии обителей. Уполномоченный Совета по Закарпатской области А. Шерстюк, описывая планы по ликвидации и будущие проблемы, констатировал неизбежность «значительных трудностей» при проведении кампании, причина которых - в ревностном отношении насельников к обителям, которые создавали их своим трудом и «смотрят на монастырские помещения как на свою ответственность». Преодолеть противостояние насельников он предлагал за счет полной поддержки кампании со стороны Святейшего Патриарха и Священного Синода [7].

Перед закрытием монастырей Г.П. Пинчук вызывал в Киев епархиальных архиереев, лично сообщая каждому о принятом союзным правительством решении закрыть конкретный монастырь епархии и согласии с этим Святейшего Патриарха. В некоторых случаях уполномоченный шел на встречу архиереям, как, например, архиепископу Черниговскому Андрею (Сухенко), согласившись отложить закрытие Густынского монастыря до праздника Пятидесятницы, который был престольным днем обители [8].

Согласно постановлению Совета Министров УССР «О закрытии некоторых монастырей и скитов на территории Украинской ССР» от 17 июня 1959 г. была определена первая группа обителей, подлежащих ликвидации: Кременецкий женский монастырь Тернопольской области 29-30 июня, Густынский женский монастырь Черниговской области 14 июля, Богородицкий женский скит в с. Бедевля Тячевского района 30 июля, Успенский женский монастырь в с. Червенево Мукачевского района 31 июля, Серафимовский женский скит в с. Заднее Иршавского района 5 августа, Тихвинский женский монастырь в г. Днепропетровске 5 августа, Духовский скит Почаевской лавры 10 августа, Овручский женский монастырь Днепропетровской области [9]. На момент принятия постановления на территории Украины находилось 40 православных монастырей и скитов [10].

Методы решительной борьбы власти на местах с монастырями в основном были схожи, поэтому можно выделить их в целостную систему. После принятия постановления Совета Министров УССР с утвержденным списком ликвидируемых монастырей устанавливались сроки закрытия, которые согласовывались с уполномоченным Г.П. Пинчуком. Процесс закрытия монастырей, по мысли советского правительства и руководства Со- 
вета, должен был проводиться максимально быстро в жестко установленные сроки, чтобы пресечь любые возможные народные волнения. С этой целью все мероприятия планировались на летний период, в который большинство населения регионов Украины, отличавшихся большим количеством обителей и высокой религиозностью, было задействовано на сельско-хозяйственной уборочной кампании.

Затем в области и особенно в окрестностях монастыря начиналась масштабная антирелигиозная пропаганда: для колхозников и рабочих проводились лекции на антицерковные темы прибывшими из аппарата ЦК Компартии Украины или обкома партии специалистами-агитаторами (высылались группы до 10-15 человек); организовывались партийные собрания колхозных и сельских первичных организаций в селах, вблизи которых находились монастыри, и антицерковные беседы даже на уровне бригад колхозов; устраивались показы кинофильмов естественно-научной и антицерковной тематики.

Отдельной трудностью для власти, имеющей идеологические последствия, являлось расселение монашествующих из закрываемых монастырей и их дальнейшее трудоустройство. Пребывание монахов среди атеистического трудового населения признавалось неблагоприятным, а поэтому при рассмотрении вопроса о ликвидации конкретного монастыря отдельное внимание уделялось вопросу переселения насельников.

Главной проблемой для властей стал архиепископ Львовский Палладий (Каминский), стремившийся любыми способами отстоять от закрытия Кременецкий женский монастырь. Первоначально, до выхода постановления Совета министров УССР, он пытался урегулировать этот вопрос «дипломатическими способами», как пишет протоиерей А. Марченко: письменно обращался к Святейшему Патриарху, беседовал с областным уполномоченным [11]. Однако его попытки не увенчались успехом. После принятия Советом Министров постановления о ликвидации монастыря архиепископ Палладий с настоятельницей Кременецкой обители оправился в Одессу к Святейшему Патриарху Алексию, надеясь заручиться его поддержкой. В ответ на просьбу владыки Святейший Патриарх сказал, что выполнить распоряжение правительства придется, но закрывать монастырь следует с особой осторожностью.

В дальнейшем архиепископ Палладий сознательно скрыл от уполномоченного Совета и местных властей свое несогласие с закрытием обители и поездку к Патриарху, соглашаясь со всеми распоряжениями, но тайно обещая насельницам отстоять обитель. В устной форме он запретил собирать вещи и готовиться к переезду насельникам Кременецкого монастыря и Духовского скита [12].
30 июня 1959 г. во время личной встречи с областным уполномоченным У.У. Крагликом архиепископ передал свое распоряжение о закрытии обители. Уполномоченный в ответ заметил, что Совету известны его тайные устные благословения вопреки своему собственному указу. «Ликвидация монастырей - большое несчастье и для нас и для вас, лучше бы этого не было», - сказал Палладий. Сообщая о новых обстоятельствах истории с архиепископом в Москву, республиканский уполномоченный Г.П. Пинчук просил Совет «немедленно договориться с патриархом Алексием о ликвидации такого досадного недоразумения» и побудить его послать телеграмму Палладию с требованием прекратить саботаж правительственного решения [13].

Получив телеграмму Московской Патриархии о закрытии монастыря, 5 июля 1959 г. он обратился к Святейшему Патриарху с письмом, в котором основную вину в противостоянии с властью возлагал на несогласных прихожан и насельниц, «поднявшихся на защиту», скрывая свою роль в этом [14]. Архиепископ полагал, что описанная им тяжелая ситуация устрашит Патриархию и побудит Патриарха встать на сторону защитников монастыря.

6 июля 1959 г. Алексий I встретился с Г.Г. Карповым, в беседе с которым был поднят вопрос о критической ситуации с закрытием Кременецкого монастыря. Убеждая председателя Совета, он указывал на ограниченные сроки переселения монахинь и необъяснимую спешку местных властей. После этой беседы Г.Г. Карпов направил сообщение в правительство и ЦК КПСС с описанием сложностей ликвидационной кампании в Тернопольской области, и вскоре все мероприятия приостановили [11].

Архиепископ Палладий ошибочно надеялся, что с помощью Святейшего Патриарха ему удастся воздействовать на Совет и областные органы власти и отменить решение о ликвидации Кременецкого монастыря и Духовского скита. Вероятно, по подсказке архиерея настоятельница монастыря игуменья Анамаиса обратилась к Н.С. Хрущеву с просьбой о помощи. Реакция властей последовала незамедлительно - 29 июля 1959 г. в г. Львов прибыли уполномоченный по УССР Г.П. Пинчук и заведующий инспекторским отделом Совета И.И. Сивенков и дали указание архиепископу Палладию прибыть в Кременец. Протоиерей А. Марченко, описывая приезд архиепископа Палладия в монастырь, отмечает первоначальный отказ архиепископа от встречи и тот факт, что он впоследствии под угрозами вынужденно приехал, но умалчивает о сложившейся ситуации после прибытия в обитель архиерея и чиновников [11].

Согласно донесению уполномоченного по Тернопольской области У.У. Краглика от 3 сентября 1959 г. архиепископ Палладий 29 июля прибыл в монастырь и в при- 
сутствии сотрудников Совета зачитал насельницам свой указ о закрытии. В ответ некоторые монахини, бывшие ранее на приеме у архиепископа, обвинили его в невыполнении обещания отстаивать монастырь до конца. Собрание завершилось выступлением республиканского уполномоченного, после которого монахини стали готовиться к переезду в г. Корец Ровенской области. «На этом собрании выяснилось, что Палладий вел двойственную линию, нам обещал одно, а монашкам, которые ездили к нему по вызову, обещал снова съездить к патриарху», - докладывал в Москву местный уполномоченный [15].

На следующий день, 30 июля, все насельницы выехали, и монастырь был окончательно закрыт. Однако сопротивление архиепископа Палладия в Москве не забыли, и Совет решил наказать непокорного архиерея. По решению Синода 31 мая 1960 г. архиепископ был переведен из Львова в Оренбургскую епархию [11].

Из-за опасений возможных волнений монахинь и верующих во время закрытия Тихвинского женского монастыря в Днепропетровске при помощи республиканского уполномоченного местные власти изменили свой порядок работы. Задолго до закрытия агитаторы областного комитета Компартии Украины начали публичные лекции среди трудовых коллективов Днепропетровска, беседовали индивидуально с отдельными семьями верующих. 5 августа 1959 г., в день закрытия, вокруг монастыря были рассредоточены сотрудники милиции в гражданской одежде, на всех прилегавших улицах дежурили регулировщики движения, прибыла пожарная команда и три машины скорой помощи. В присутствии областного уполномоченного Днепровского сотрудники облисполкома и обкома партии приступили к закрытию, которое было завершено к концу дня [16].

Монастыри и скиты Закарпатской области власти закрывали с 30 июля по 5 августа. Закарпатский облисполком кроме агитационных мероприятий, главным образом, стремился совместно с уполномоченным к «обмирщению» монахинь и их возвращению к гражданской жизни. Для этого областной уполномоченный А. Шерстюк неоднократно встречался с родственниками монахинь, в беседах с которыми убеждал забрать насельниц на постоянное проживание в свои семьи. Но лишь немногочисленная группа монахинь вернулась к родственникам, а большинство переселились в Николаевский монастырь г. Мукачево и скит в с. Липча. Характерным отражением политики Совета является предложение уполномоченного проводить в будущем сокращение монастырей «только по церковной линии». По его мнению, отстраненность руководства епархии от закрытия монастырей в глазах верующих возлагала всю ответственность на местную власть, а не церковную иерархию, от чего нужно избавиться, поэтому «техническую» помощь советским органам следовало оказывать «только по просьбе руководства епархии или монастыря» [17].

О результатах выполнения плана по закрытию монастырей республиканский уполномоченный Г.П. Пинчук доложил Совету 19 августа 1959 г. В докладной записке он отмечал содействие некоторых облисполкомов, отвлекавших верующее население на колхозные работы по сбору урожая, удовлетворительную организацию переселения монашествующих в другие монастыри. Также в сообщении объяснялись причины волнений при закрытии Кременеского и Овручского монастырей, которой противились «некоторые монахини и кликуши», и сообщалось, что часть монахинь Кременецкой обители во время закрытия принудительно отправлены в психбольницу. Однако окончательные результаты отличались от поставленных руководством Совета задач по мирной ликвидации монастырей [18].

Итоги кампании 1959 г. были подведены на заседании Совета от 4-7 сентября, центральной темой обсуждения стали доклады заведующего инспекторским отделом Совета И.И. Сивенкова и уполномоченного по УССР Г.П. Пинчука. Констатируя плановый характер и долгую подготовительную работу перед закрытием обителей, руководство Совета дипломатично сваливало вину в народных волнениях на «провокации церковников и хулиганских элементов», перекладывая ответственность с местных властей на духовенство и архиереев. Отдельным пунктом решения Совета явилось информирование Святейшего Патриарха Алексия о намеченных планах по сокращению и решение рекомендовать ему «дать указания епископам о предварительном проведении мероприятий с их стороны по сокращению монастырей» и «прекратить прием новых монашествующих во все монастыри, подлежащие сокращению».

Члены Совета рассмотрели проект плана Г.П. Пинчука на 1960 г. о сокращении 10 монастырей и утвердили его. «В связи с наличием фактов, компрометирующих Львовского епископа Палладия», было решено предложить Г.Г. Карпову обсудить с Святейшим Патриархом возможность его перевода на другую кафедру, что вскоре и состоялось [19].

Во время второго периода наступления в 1960 г. были закрыты 8 обителей в г. Полтаве, Городище Хмельницкой обл., в с. Устенском Ровенской области, в с. Копашнево и Драгово Закарпатской области, в с. Крещатик Черновицкой области, в с. Бар Винницкой области и в г. Киеве (Введенский монастырь)[10]. Уполномоченный Г.П. Пинчук в докладе председателю Совета подчеркивал собственный успех в скорости проведения кампании: если в 1959 г. сокращение длилось 52 дня, то в 1960 г. прошло за 23 дня, а на территории республики осталось только 20 обителей [20]. 
Таким образом, разгром антипартийной группы в 1957 г. и укрепление положения высших партийных кругов в советской властной вертикали стали причиной поворота в государственно-церковных отношениях. В результате аппаратного ослабления Совета по делам Русской Православной Церкви как наследия И.В. Сталина и лично его председателя Г.Г. Карпова высшим политическим руководством СССР был поддержан «жесткий» курс политики в отношении Церкви, который ознаменовался выходом в 1958 г. постановления ЦК КПСС «О записке отдела пропаганды и агитации ЦК КПСС по союзным республикам “О недостатках научно-атеистической пропаганды"».

В рамках объявленной новой войны с религией в СССР была начата полномасштабная кампания, одним из главных звеньев которой явилось ослабление финансового и административного положения Московской Патриархии. Под удар были поставлены главные духовные и экономические центры - православные монастыри, а существование монашеской жизни было решено уничтожить. Первый этап войны с религией был проведен в 1958-1959 гг. За этот год на территории Украинской ССР, самой большой республике по количеству православных обителей, были закрыты 8 монастырей и скитов. Попытки оказания сопротивления со стороны епископов, монашествующих и верующих жестко подавлялись.

При этом центральный аппарат Совета настаивал на неспешном проведении кампании, результатом которой должно было стать полное уничтожение монашества в СССР. Механизм ликвидации монастырей, разработанный аппаратом Совета и скорректированный с учетом ошибок первого года кампании, в 1960 г. качественно улучшили, вынудив партийные и советские органы власти на местах решать проблемы не только закрытия монастыря, а и дальнейшего распределения монашествующих.

\section{ЛИТЕРАТУРА}

1. Марченко А.Н. Религиозная политика Советского государства в годы правления Н.С. Хрущева и ее влияние на церковную жизнь в СССР. М., 2010. С. 56.

2. Чумаченко Т.В. Государство и русская православная церковь в 1958-1964 годах: новая политическая война с религией, церковью и верующими // Вестник Челябинского государственного университета. - 2014. № 19 (348). Право. Вып. 39. С. 82.

3. ГАРФ. Ф. Р-6991. Оп. 1. Д. 1632.Л. 26.

4. ГАРФ. Ф.Р-6991. Оп. 1. Д. 1585. Л. 34-36.

5. ГАРФ. Ф.Р-6991. ОП. 1. Д. 1632. Л. 49.

6. ГАРФ. Ф. Р-6991. Оп. 1. Д. 1632. Л. 12-13, 101.

7. ГАРФ. Ф.Р-6991. Оп. 1. Д. 1632. Л. 63.

8. ГАРФ. Ф.Р-6991. Оп. 1. Д. 1633. Л. 13, 14.

9. ГАРФ. Ф. Р-6991. ОП. 1. Д. 1632. Л. 193.

10. ГАРФ. Ф. Р-6991. Оп. 1. Д. 1788. Л. 73.

11. Марченко А.Н., прот, Алексий (Годлевский), иером. Сопротивление архиепископа Львовского и Тернопольского Палладия (Каминского) закрытию монастырей на Западной Украине в начале хрущевских гонений (1958-1960 гг.) // Христианское чтение. 2018. № 6. С. 175-178.

12. ГАРФ. Ф.Р-6991. Оп. 1. Д. 1632.Л. 185.

13. ГАРФ. Ф. Р-6991. ОП. 1. Д. 1632.Л. 181, 182, 186.

14. ГАРФ. Ф.Р-6991. ОП. 2. Д. 261. Л. 265-266.

15. ГАРФ. Ф.Р-6991. ОП. 1. Д. 1633. Л. 32.

16. ГАРФ. Ф. Р-6991. Оп. 1. Д. 1632. Л. 206.

17. ГАРФ. Ф.Р-6991. Оп. 1. Д. 1632.Л. 194, 204.

18. ГАРФ. Ф.Р-6991. Оп. 1. Д. 1633. Л. 21-24.

19. ГАРФ. Ф. Р-6991. ОП. 1. Д. 1633. Л. 2-5.

20. ГАРФ. Ф.Р-6991. Оп. 1. Д. 1788. Л. $75,85$.

(c) Гоюк Серафим Михайлович (samgoyuk@yandex.ru). Журнал «Современная наука: актуальные проблемы теории и практики» 